\title{
Perceived stress: role and levels of demographics - a cross-sectional study of textile industry employees
}

DOI: $10.35530 / I T .071 .02 .1643$

\section{Perceived stress: role and levels of demographics - a cross-sectional study of textile industry} employees

Work stress adversely affects individual and organizational performance. This paper aims at investigating the perceived stress among the employees of textile industry employees and how the employees' perceived stress level (EPSL) is linked with different demographic variables. Data was collected from 1212 employees working in 23 export-based textile organizations using primarily Sheldon Cohen's PSS-10. Descriptive analysis, t-tests, and ANOVA-tests were performed to achieve the objectives of the study. $70 \%$ of the participants were found to be undergoing stress amongst $21 \%$ were in the severe level of stress while $40 \%$ in higher level. The demographic variables: gender, marital status, salary, position, job experience, family size, and size of the organization, were found to have significant effect on the perceived stress levels. The study revealed numbers of variables (demographic) that directly or indirectly affect the employees' perceived stress level (EPSL). There is a need to understand the complexity of stress phenomenon using a proactive approach, so that the stress management and interventions strategies can be designed to be effective and implemented accordingly. Findings of this research support the research community in an attempt to unfold complexity of stress phenomenon and study results can be utilized as a job design guideline for more acceptable and viable stress management interventions.

Keywords: demographics, employees, PSS-10, perceived stress, textile

\section{Stresul perceput: rolul și nivelurile demografice - un studiu transversal asupra angajaților din industria textilă}

Stresul de la locul de muncă afectează negativ performanțele individuale și organizaționale. Acest articol are ca obiectiv analiza stresului perceput în rândul angajaților din industria textilă și modul în care nivelul de stres perceput al angajaților (EPSL) este influențat de diferite variabile demografice. Datele au fost colectate de la 1212 angajați, care lucrează în 23 de organizații în domeniul exportului de produse textile, folosind în principal indicatorul PSS-10 al lui Sheldon Cohen. Analiza descriptivă, testele-t și testele ANOVA au fost efectuate pentru a atinge obiectivele studiului. S-a constatat că $70 \%$ dintre participanți suferă de stres, dintre care $21 \%$ au prezentat un nivel sever de stres, iar $40 \%$ un nivel superior de stres. Variabilele demografice: sexul, starea civilă, salariul, funcţia, experiența la locul de muncă, numărul de membri ai familiei și mărimea organizației influențează semnificativ nivelurile de stres percepute. Studiul a relevat un număr de variabile (demografice), care influențează direct sau indirect nivelul de stres perceput de către angajați (EPSL). Este necesară înțelegerea complexității fenomenului de stres folosind o abordare proactivă, astfel încât gestionarea stresului și strategiile de intervenție să fie eficiente și implementate în consecință. Concluziile acestei cercetări susțin comunitatea de cercetare în încercarea de a analiza complexitatea fenomenului de stres, iar rezultatele studiului pot fi utilizate ca ghid de proiectare a locului de muncă pentru intervenții viabile de gestionare a stresului.

Cuvinte-cheie: demografie, angajați, PSS-10, stresul perceput, textile

\section{INTRODUCTION}

\section{Background and objectives of the study}

Work stress is a global issue. In Great Britain, in the year 2017-2018: work-related stress, anxiety or depression were found as major causes for $44 \%$ of the work-related ill-health cases where about $57 \%$ of the working days were found to be lost because of health-related issues [1]. The textile industry is considered as one of the largest manufacturing industries in Pakistan. The sector supports $8.5 \%$ to the gross domestic product (GDP) and is a source of employment to about $30 \%$ of the 49 million workforce of the country. With fifty two percent of total exports, it continues to be the mainstay of the country's exports [2]. Work stress has become a major issue for the organizations where textile organizations have no exemption. This research aims at investigating the intensity of perceived stress among the employees of textile industry organizations and how perceived stress is linked with different demographic variables. The study is a part of a big research project of which three of the works have already been published [3-5], with novel major parts presented in this paper. 
Stress affects the human body adversely and results in work-related musculoskeletal disorders (WMSDs) and impacts individual and organizational work performance negatively [6-8]. It results in reduced efficiency, reduced capacity for work schedules, diminished zeal or work devotion, lack of creativity, absence of compassion for the organization, lost commitment, self-esteem, and increased occurrence of "perceived contract breach" [9-12]. It can easily be concluded that stress has its effects on all the functions being performed in an organization and due deliberation ought to be given to manage it.

\section{Literature review and research gap}

Several studies have been performed to determine individuals' perceived stress levels and their association with the group demographics. The demographics of the players and entrepreneurs were found to play a major role in perceiving the impacts of stressors [13-14]. Women were reported to be more stressful than men [4,15-17]. Likewise, single employees have been found to be more stressful than married [1]. Increases in the educational level of the participants, has been found associated with a decrease in their perceived stress scores [1]. A study on radiographers revealed that $63 \%$ of the subjects indicated high to severe levels of stress [16] whereas another performed on textile workers yielded $28 \%$ as stressful [18]. A positive correlation was found between HRST (Human Resource in Science and Technology) and innovative projects while it was not found between people with tertiary education and innovative process [2]. Major emphasis in the earlier stress related studies has been seen in sports, medical services, and employment in a broad-spectrum besides some segments like teaching [9, 19-21]. The stress literature on the textile industry employees is very limited and the available literature does not cover the sector as a whole [22] whereas this study encompasses the entire area of the textile industry. In Pakistan textile and clothing sector, there is a need to deploy efficient research and development activities [23]. The present study attempts to unfold work stress phenomenon.

\section{METHOD}

\section{Participants}

In the study, 1212 personnel from 23 diverse organizations were randomly selected for the data collection. The employees who were the subjects for this research worked at all levels in the four major areas of the textile sector, explicitly: fiber and fabric manufacturing; apparel manufacturing; socks manufacturing; and home textiles. They were from different functioning areas of the establishments (see table 1).

\section{Survey}

So as to reach the desired objectives of this crosssectional study, information was gathered through a survey. Earlier, trained staffs talked to each participant about the rationale of the research and how to record the responses. Respondents were informed that the data collection was anonymous and no specific information would be shared with anyone at any stage of the research and the information would be used only for research purposes.

\section{Instrument}

The instrument consisted of Cohen's Perceived Stress Scale-10 (PSS-10) [24] and nine demographic variables. PSS-10 is one of the scales commonly used to record the individuals' perceived stress levels. Since its development in 1983, it has been a widely used by the researchers to evaluate individuals' and group stress levels [25-26]. In the PSS-10 part of the instrument, subjects answered on a 5-point scale which ranged from 0 (never) to 4 (always), 0 indicating No Stress and 4 indicating High Stress. The subjects were supposed to go for any number of the scale as per their responses. The responses to 10 questions were subsequently summed to generate the perceived stress score, where higher scores indicate greater psychological stress. The internal consistency of the PSS-10 part of the instrument was checked through Cronbach's alpha and found reliable with the value of 0.74 .

\section{Statistical procedures}

Descriptive analysis, independent sample t-test, and a One-Way between subjects ANOVA using the SPSS 23.0 were deployed to measure the employees' perceived stress level (EPSL) and to identify the role of demographics on it.

\section{RESULTS AND DISCUSSION}

\section{Perceived stress}

Psychological stress has been shown to contribute to poorer health practices, augmented disease risk, more frequent health service consumption, and increased mortality [30].

\section{PSS scores}

The total PSS score mean was 14.59 while it was 14.43 for male and 15.70 for female employees, table 1. A trend of decrease in stress appeared with an increase in educational level excluding graduates and postgraduates. Stress score was higher for workers (15.48) and lower for supervisors (13.22). A similar trend was seen for job experience where mean PSS score decreased with increase in job experience exclusive of above 15 years.

\section{Perceived stress levels}

There are no cut-offs in the PSS scores, there are only comparisons between people within the sample [27]. Thus, for the purpose, individuals' perceived stress scores were interpreted as $0-7=$ no stress, 8-11 = low stress, 12-15 = moderate stress, 16-20 = high stress, $21+=$ severe stress [4]. Subsequently, table 1, figures 1 and 2 show statistics of the employees referring to their perceived stress levels. In further 


\begin{tabular}{|c|c|c|c|c|c|c|c|c|c|}
\hline \multicolumn{10}{|c|}{ DEMOGRAPHICS, PERCEIVED STRESS SCALE SCORES AND EMPLOYEES CATEGORY $(\mathrm{N}=1212)$} \\
\hline \multirow{3}{*}{\multicolumn{2}{|c|}{ Demographics }} & \multicolumn{2}{|c|}{ Frequency } & \multicolumn{2}{|c|}{ PSS score } & \multicolumn{4}{|c|}{$\begin{array}{c}\text { Employees category with respect } \\
\text { to stress }\end{array}$} \\
\hline & & \multirow{2}{*}{ No. } & \multirow{2}{*}{ Percentage } & \multirow{2}{*}{ Mean } & \multirow{2}{*}{$\begin{array}{l}\text { Standard } \\
\text { deviation }\end{array}$} & \multicolumn{2}{|c|}{ Not stressful } & \multicolumn{2}{|c|}{ Stressful } \\
\hline & & & & & & No. & Percentage & No. & Percentage \\
\hline \multirow{2}{*}{ Gender } & Male & 1059 & 87.4 & 14.43 & 5.43 & 325 & 30.7 & 734 & 69.3 \\
\hline & Female & 153 & 12.6 & 15.7 & 6.01 & 39 & 25.5 & 114 & 74.5 \\
\hline \multirow{3}{*}{$\begin{array}{l}\text { Marital } \\
\text { status }\end{array}$} & Married & 903 & 74.5 & 14.24 & 5.41 & 298 & 33 & 605 & 67 \\
\hline & Single & 299 & 24.7 & 15.49 & 5.64 & 66 & 22.1 & 233 & 77.9 \\
\hline & Others & 10 & 0.8 & 19.6 & 6.88 & 0 & 0 & 10 & 100 \\
\hline \multirow{6}{*}{ Department } & HR & 56 & 4.6 & 14.42 & 6.77 & 21 & 37.5 & 42 & 62.5 \\
\hline & $\begin{array}{l}\text { Accounts and } \\
\text { finance }\end{array}$ & 43 & 3.5 & 14.72 & 5.17 & 13 & 30 & 30 & 70 \\
\hline & \begin{tabular}{|l|}
$\begin{array}{l}\text { Marketing and } \\
\text { export }\end{array}$ \\
\end{tabular} & 87 & 7.2 & 14.85 & 5.57 & 25 & 29 & 62 & 71 \\
\hline & Production & 909 & 75 & 14.69 & 5.45 & 263 & 29 & 646 & 71 \\
\hline & Administration & 42 & 3.5 & 13 & 5.69 & 16 & 38 & 26 & 62 \\
\hline & Any other & 75 & 6.2 & 14.05 & 5.35 & 26 & 35 & 49 & 65 \\
\hline \multirow{4}{*}{$\begin{array}{l}\text { Job } \\
\text { experience }\end{array}$} & $<5$ years & 388 & 32 & 15.03 & 5.39 & 88 & 22.7 & 300 & 77.3 \\
\hline & $5-10$ years & 433 & 35.7 & 14.7 & 5.53 & 136 & 31.4 & 297 & 68.6 \\
\hline & $11-15$ years & 234 & 19.3 & 13.55 & 5.18 & 85 & 36.3 & 149 & 63.7 \\
\hline & $>15$ years & 157 & 13 & 14.78 & 6.11 & 55 & 35 & 102 & 65 \\
\hline \multirow{4}{*}{ Position } & worker & 512 & 42.2 & 15.48 & 5.61 & 121 & 23.6 & 391 & 76.4 \\
\hline & supervisor & 445 & 36.7 & 13.22 & 5.27 & 180 & 40 & 265 & 60 \\
\hline & manager & 241 & 19.9 & 15.24 & 5.22 & 58 & 24 & 183 & 76 \\
\hline & executive & 14 & 1.2 & 14.57 & 6.61 & 5 & 35.7 & 9 & 64.3 \\
\hline \multirow{4}{*}{$\begin{array}{l}\text { Salary } \\
\text { (monthly) in } \\
\text { Pak Rupee }\end{array}$} & $<20 K$ & 585 & 48.3 & 15.07 & 5.71 & 156 & 26.7 & 429 & 73.3 \\
\hline & $20 \mathrm{~K}-50 \mathrm{~K}$ & 493 & 40.7 & 13.83 & 5.25 & 173 & 35 & 320 & 65 \\
\hline & $50 \mathrm{~K}-100 \mathrm{~K}$ & 116 & 9.6 & 15.74 & 5.33 & 29 & 25 & 87 & 75 \\
\hline & $<100 \mathrm{~K}$ & 18 & 1.5 & 12.5 & 4.27 & 6 & 50 & 12 & 50 \\
\hline \multirow{6}{*}{ Family size } & two or less & 95 & 7.8 & 15.77 & 5.73 & 24 & 25.3 & 71 & 74.7 \\
\hline & three & 133 & 11 & 14.19 & 5.83 & 47 & 35.3 & 86 & 64.7 \\
\hline & four & 329 & 27.1 & 13.68 & 5.31 & 115 & 35 & 214 & 65 \\
\hline & five & 323 & 26.7 & 14.38 & 5.41 & 105 & 32.5 & 218 & 67.5 \\
\hline & six & 155 & 12.8 & 15.53 & 5.08 & 28 & 18 & 127 & 82 \\
\hline & seven or more & 177 & 14.6 & 15.52 & 5.78 & 45 & 25.4 & 132 & 74.6 \\
\hline \multirow{5}{*}{$\begin{array}{l}\text { Educational } \\
\text { level }\end{array}$} & $<$ Matriculation & 175 & 14.4 & 16.51 & 5.5 & 38 & 21.7 & 137 & 78.3 \\
\hline & Matriculate & 361 & 29.8 & 14.22 & 5.57 & 113 & 31.3 & 248 & 68.7 \\
\hline & Intermediate/DAE & 322 & 26.6 & 13.98 & 5.33 & 112 & 34.8 & 210 & 65.2 \\
\hline & Graduate & 267 & 22 & 14.38 & 5.33 & 78 & 29.2 & 189 & 70.8 \\
\hline & Post graduate & 87 & 7.2 & 15.24 & 5.78 & 23 & 26.4 & 64 & 73.6 \\
\hline \multirow{2}{*}{$\begin{array}{l}\text { Size of the } \\
\text { organization }\end{array}$} & Large & 1053 & 86.9 & 14.2 & 5.54 & 340 & 33 & 688 & 67 \\
\hline & Small & 159 & 13.1 & 17.23 & 4.72 & 24 & 13 & 160 & 87 \\
\hline \multicolumn{2}{|l|}{ Overall } & 1212 & 100 & 14.59 & 5.52 & 364 & 30 & 848 & 70 \\
\hline
\end{tabular}

analysis, No Stress and Low Stress were summed together to correspond to Not Stressful while the scales: Moderate, High, and Severe were combined as Stressful. It is worrisome that only $364(30 \%)$ were in the Not Stressful group while a vast majority (around $70 \%$ of the sample population) was Stressful. Figure 3 shows that amongst the stressful subjects, a large group is in higher stress levels.
Role of demographics on the perceived stress

In order to ascertain the role of demographics on the individuals' perceived stress, independent sample t-tests and One-way ANOVA tests between subjects were deployed.

Independent sample t-test

Independent-sample t-tests were conducted to compare perceived stress score of male and female 


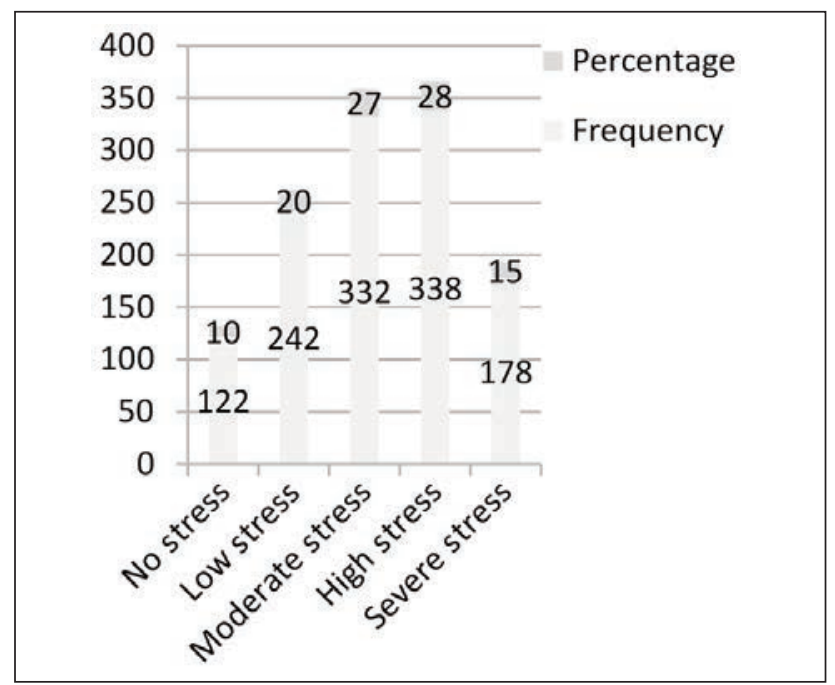

Fig. 1. Number and percentage of employees with respect to perceived stress levels $(\mathrm{N}=1212)$

employees, married and un-married employees, and employees of SMEs and employees of large organizations. There was a significant difference in the scores for male $(M=14.43, S D=5.43)$ and female $(M=15.70, S D=6.01)$ employees; $t(1210)=-2.65$, $p=0.008 ;$ married $(M=14.24, S D=5.43)$ and single $(M=15.49, S D=5.64)$ employees; $t(1200)=-3.41$, $p=0.001$; and SME employees $(M=17.00, S D=4.72)$ and large organization $(M=14.16, \quad S D=5.54)$ employees; $\mathrm{t}(1210)=-6.53, p=0.000$ (table 2). These results suggest that gender, marital status, and size of the organization do have an effect on the perceived stress levels of the employees. Specifically, results suggest that female employees, single employees, and SME employees are more stressful. This is in line with the Romanian textile and clothing industry where the implementation of performance management practices was found to be better in large organizations than SMEs [28].

\section{One-way ANOVA between subjects}

One-way ANOVAs between subjects were conducted to compare the role of employees' department, job experience, position, salary, family size, and educational level on their perceived stress levels. It revealed that working in different departments does not have a significant effect on the employees' perceived stress level $(E P S L)(p<0.05)[F(5,1206)=$ $0.955, p=0.444]$ whereas job experience significantly affects $(p<0.05)$ on EPSL $[F(3,1208)=3.71$,

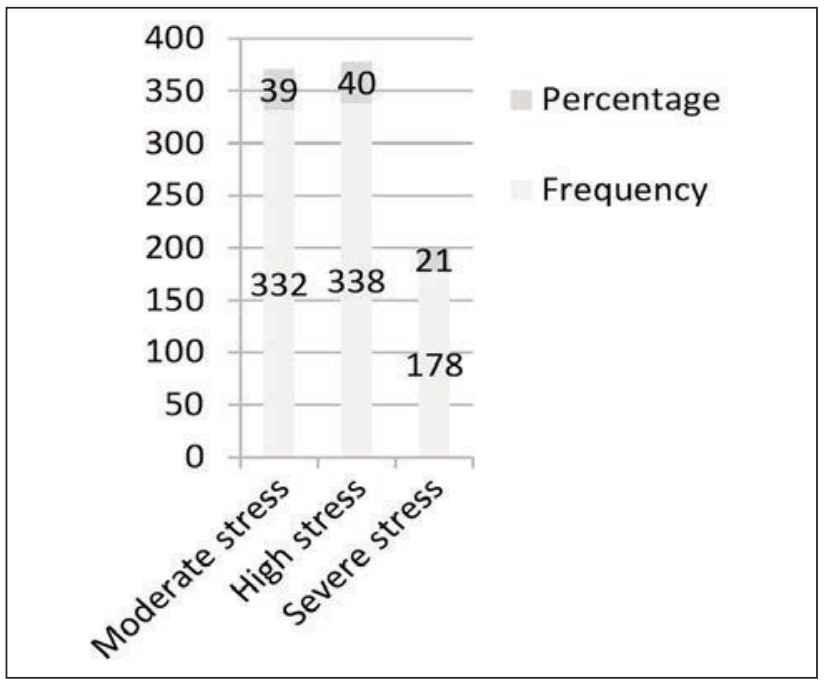

Fig. 2. Statistics of stressful employees $\mathrm{N}=848$

$p=0.011$ ]. Likewise, job experience was found to have an effect on EPSL. Specifically, the EPSL having job experience less than five years is more and results show that employees were more stressful at early stage of their careers. Ones' position in an organization is perceived as an important attribute as the study revealed that position significantly affects the EPSL $(p<0.05)[F(3,1208)=15.12, p=0.000]$, table 3 . The analysis revealed a significant effect $(p<0.05)$ of salary on $\operatorname{EPSL}[F(3,1208)=7.21, p=0.000]$. These results suggest that the salary of employee has an effect on EPSL. The EPSL in the lower salary category was higher.

Likewise, the effect of family size was found significant $(p<0.05)[F(5,1206)=4.89, p=0.000]$, table 3 . These results suggest that the family size of the employee has an effect on EPSL. Specifically, EPSL with family sizes, two or less, six and seven or more were higher. The educational level has a significant impact on perceived level of stress $(p<0.05)[F(4$, $1207)=7.26, p=0.000$ ], table 3 . Employees with lower educational level are more stressful.

In summary, the independent sample t-test and a one-way between subjects ANOVA results indicate that the demographics gender, marital status, job experience, monthly salary, position, family size, educational level and the employees' organization size significantly affect their perceived stress scores.

\begin{tabular}{|c|c|c|c|c|c|}
\hline \multicolumn{2}{|c|}{ INDEPENDENT SAMPLES TESTS: GENDER, MARITAL STATUS, ORGANIZATION SIZE } \\
\hline \multirow{2}{*}{ Variables } & \multicolumn{2}{|c|}{$\begin{array}{c}\text { Levene's test for equality } \\
\text { of variances }\end{array}$} & \multicolumn{3}{|c|}{ t-test for equality of means } \\
\cline { 2 - 6 } & $\mathrm{F}$ & Sig. & $\mathrm{t}$ & $\mathrm{df}$ & Sig. (2-tailed) \\
\hline Gender and PSS score & 2.94 & 0.087 & -2.655 & 1210 & 0.008 \\
\hline Marital status and PSS score & 0.084 & 0.772 & -3.412 & 1200 & 0.001 \\
\hline Organization size and PSS score & 5.555 & 0.019 & -6.528 & 1210 & 0 \\
\hline
\end{tabular}




\begin{tabular}{|c|c|c|c|c|c|c|}
\hline \multicolumn{7}{|c|}{ PSS SCORE - A ONE-WAY BETWEEN SUBJECTS ANOVA RESULTS } \\
\hline \multicolumn{2}{|c|}{ Demographics } & Sum of squares & df & Mean square & $\mathbf{F}$ & Sig. \\
\hline \multirow{2}{*}{ Department } & between groups & 145.512 & 5 & 29.102 & 0.955 & 0.444 \\
\hline & within groups & 36740.576 & 1206 & 30.465 & & \\
\hline \multirow{2}{*}{ Job experience } & between groups & 336.677 & 3 & 112.226 & 3.709 & 0.001 \\
\hline & within groups & 36549.411 & 1208 & 30.256 & & \\
\hline \multirow{2}{*}{ Position } & between groups & 1335.223 & 3 & 445.074 & 15.123 & 0.000 \\
\hline & within groups & 35550.865 & 1208 & 29.430 & & \\
\hline \multirow{2}{*}{ Salary (monthly) } & between groups & 648.671 & 3 & 216.224 & 7.208 & 0.000 \\
\hline & within groups & 36237.418 & 1208 & 29.998 & & \\
\hline \multirow{2}{*}{ Family size } & between groups & 733.102 & 5 & 146.620 & 4.891 & 0.000 \\
\hline & within groups & 36152.986 & 1206 & 29.978 & & \\
\hline \multirow{2}{*}{ Educational level } & between groups & 867.089 & 4 & 216.772 & 7.264 & 0.000 \\
\hline & within groups & 36018.999 & 1207 & 29.842 & & \\
\hline
\end{tabular}

\section{CONCLUSION}

The research aimed at investigating the perceived stress levels of the textile industry employees and how perceived stress is linked to different demographic variables. The study revealed that about $70 \%$ of participants were stressed at their jobs, though levels of their stress were different. The demographic factors gender, marital status, job experience, salary, educational level, family size, and the organization size have significant effects on the employees' perceived stress levels. However, the demographic variable department had no significant effect on stress. The situation demands implementation of effective interventions to protect the employees from unfavourable impacts of the stress which in turn will enhance the organizational performance. The findings of this work further highlight that work stress is a complex phenomenon which is influenced by a number of internal and external factors; so before devising some control or prevention strategies, it should be investigated appropriately so that effectiveness of the interventions might be enhanced. The findings of this study provide an opportunity to understand the complex nature of work stress phenomenon where the relationship of different demographic variables with the perceived stress have been studied in depth. Though the findings of this research are linked to the textile sector organizations; it provides a good insight about the complexity of stress phenomenon and can be linked with similar kind of working environments based on the nature of work. The results of the study have been detailed but as there has been no attempt to consider why things might be as they are, there is little in the way of guidance for those that want to use the results in the devising of prevention strategies. So, it would have been useful to have had an assessment of the likely causes of the difference between men and women so that these causes might be removed by the strategy.

\section{ACKNOWLEDGEMENT}

The study was supported by the UET, Lahore, Pakistan under grant Number ORIC/94-ASRB/138. Cooperation of industry in data collection is highly acknowledged.

\section{REFERENCES}

[1] Hoboubi, N., Choobineh, A., Kamari, F., The Impact of Job Stress and Job Satisfaction on Workforce Productivity in an Iranian Petrochemical Industry, In: Safety and Health at Work, 2017, 8, 1, 67-71

[2] Simion, C.-P., et al., Economic and IT determinants of innovative projects in the textiles, wearing apparel, leather and related products industry, In: Industria Textila, 2018, 69, 4, 338-344, http://doi.org/10.35530/IT.069.04.1478

[3] Ahmad, A., et al., Causes of Workplace Stress in Textile Industry of Developing Countries: A Case Study from Pakistan, In: Advances in Social \& Occupational Ergonomics, Advances in Intelligent Systems and Computing, Springer Orlando, Cham, 2017, 487, 283-294

[4] Ahmad, A., et al., Workplace Stress Assessment Among Managers of Textile Industries at Developing Countries: A Case Study from Pakistan, In: Advances in Human Factors, Business Management and Leadership, AHFE 2017, Springer, Cham, 2018, 594, 382-391

[5] Aftab, A., et al., Effects of Workplace Stress on Managers of Textile Industries of Developing Countries: A Case Study from Pakistan, In: Advances in Human Factors, Business Management and Society, AHFE 2018, Advances in Intelligent Systems and Computing, Springer, Cham, 2018, 783, 500-507

[6] Sharma, R., Singh, R., Work-related musculoskeletal disorders, job stressors and gender responses in foundry industry, In: International Journal of Occupational Safety and Ergonomics, 2014, 20, 2, 363-373 
[7] Tucker, M., Jimmieson, L., Nerina L., Oei, TP., The relevance of shared experiences: A multi-level study of collective efficacy as a moderator of job control in the stressor-strain relationship, In: Work \& Stress: An International Journal of Work, Health and Organizations,2013, 27, 1, 1-21

[8] Senaratne, S., Rasagopalasingam, V., The causes and effects of work stress in construction project managers: the case in Sri Lanka, In: International Journal of Construction Management, 2017, 17, 1, 65-75

[9] Adriaenssens, J., Veronique, D., Maes, S., Causes and consequences of occupational stress in emergency nurses, a longitudinal study, In:Journal of Nursing Management, 2015, 23, 3, 346-382

[10] Bridger, R., Day, A., Mortan, K., Occupational stress and employees turnover, In: Ergonomics, 2013, 56, 11, 1629-1639

[11] Choi, S., Lee, J., Park, H., The effects of Psychological problems in employees' stress, self esteem, and organizational committment: the case of South Korean workplaces, In: Journal of Workplace Behavioural Health, 2015, 30, 1, 2, 179-190

[12] Xavier, I., Jepsen, D., The Impact of Specific Job Stressors on Psychological Contract Breach and iolation, In: Human Factors and Ergonomics in Manufacturing \& Service Industries, 2015, 25, 5, 534-547

[13] Arnold, R., Fletcher, D., Daniels, K., Demographic differences in sport performers' experiences of organizational stressors, In: Scandinavian Journal of Medicine \& Science in Sports, 2016, 26, 3, 348-358

[14] Baron, R., et al., Why Entrepreneurs Often Experience Low, Not High, Levels of Stress: The Joint Effects of Selection and Psychological Capital, In: Journal of Management, 2016, 42, 3, 348-358

[15] Vieiraa, E., et al., Symptoms and risks for musculoskeletal disorders among male and female footwear industry workers, In: International Journal of Industrial Ergonomics, 2015, 48, 110-116

[16] Ashong, G., et al., Effects of occupational stress and coping mechanisms adopted by radiographers in Ghana, In: Radiography, 2015, 22, 2, 112-117

[17] Wiklund, M., et al., Subjective health complaints in older adolescents are related to per-ceived stress, anxiety and gender - A cross-sectional school study in Northern Sweden, In: BMC Public Health, 2012, 12, 993, 1471-2458

[18] Kitronza, P., Mairiaux, P., Stress among Textile Workers in the Democratic Republic of Congo, In: Tropical Medicine and Health, Occupational, 2015, 43, 4, 223-231

[19] Kizhakkeveettil, A., et al., Perceived stress and fatigue among students in a doctor of chiropractic training program, In: Journal of Chiropractic Education, 2017, 31, 8-13

[20] Pettit, M., DeBarr, K., Perceived Stress, Energy Drink Consumption, and Academic Performance Among College Students, In: Journal of American College Health, 2011, 59, 335-341

[21] Baka, Ł., Bazińska, R., Polish adaptation of three self-report measures of job stressors: the Interpersonal Conflict at Work Scale, the Quantitative Workload Inventory and the Organizational Constraints Scale, In: International Journal of Occupational Safety and Ergonomics, 2016, 22, 1, 32-39

[22] Steinisch, M., et al., Work stress: Its components and its association with self-reported health outcomes in a garment factory in Bangladesh - Findings from a cross-sectional study, In: Health \& Place, 2013, 24, 123-130

[23] Kanat, S., et al., SWOT analysis of Pakistan's textile and clothing industry, In: Industria Textila, 2018, 69, 502-510, http://doi.org/10.35530/IT.069.06.1488

[24] Cohen, S., Kamarck, T., Mermelstein, R., A global measure of perceived stress, In: Journal of Health and Social Behavior, 1983, 24, 4, 385-396

[25] Karkoulian, S., Srour, J., Sinan, T., A gender perspective on work-life balance, perceived stress, and locus of control, In: Journal of Business Research, 2016, 69, 11, 4918-4923

[26] Cohen, S., Janicki-Deverts, D., Miller, G., Psychological stress and disease, In: Journal of the American Medical Association, 2007, 298, 1685-1687

[27] Eby, L., et al., Are bad experiences stronger than good ones in mentoring relationships? Evidence from the protégé and mentor perspective, In: Journal of Vocational Behavior, 2010, 77, 81-92

[28] Girneata, A., et al., Performance management practices in Romanian textile and clothing companies, In: Industria Textila, 2015, 66, 108-113

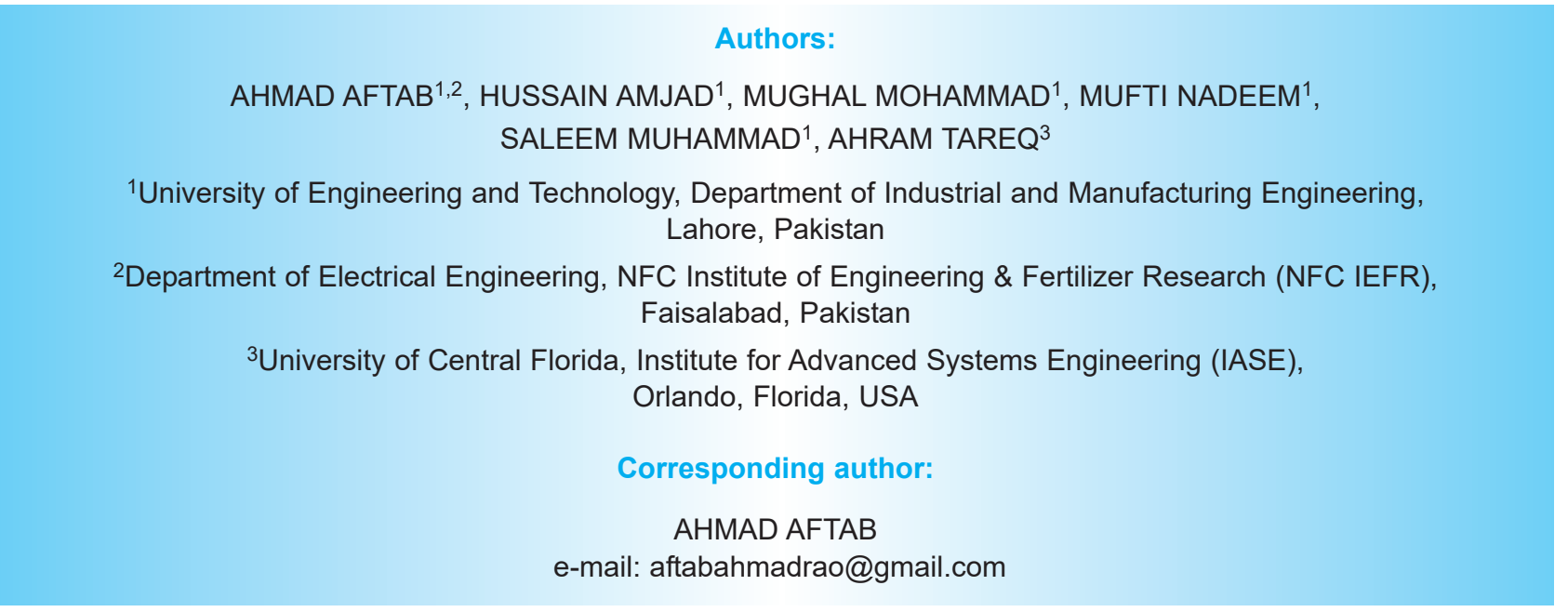

